\title{
Composition and structure of the fig wasp community in Amazonia
}

\author{
Raquel Ribeiro de Souza CASTRO ${ }^{1 *}$, Alinne Costa Cavalcante REZENDE ${ }^{1}$, Rosemary Aparecida ROQUE ${ }^{1}$ \\ Silvia Cassia Brandão JUSTINIANO ${ }^{1}$, Otilene dos Anjos SANTOS ${ }^{1}$ \\ 1 Universidade Nilton Lins, Pró-reitoria de Pesquisa e Pós-graduação Av. Professor Nilton Lins, 3259 - Parque das Laranjeiras Manaus-CEP: 69.058-030 AM \\ *Corresponding author: raquel34castro@hotmail.com
}

\section{ABSTRACT}

An understanding of the complex ecological interaction between fig wasps and their host plants in Amazonia requires previous knowledge of their distribution and diversity. The objective of this study was to describe the composition and structure of the wasp community associated with four species of Ficus in the municipal area of Manaus, Amazonas, Brazil. A total of 600 syconia from four species were collected. The study species were: Ficus obtusifolia Kunth; Ficus citrifolia Mill; F. americana subspecies guianensis Desv. form mathewsii; and F. americana subspecies guianensis Desv. form parkeriana. Statistical analyses were used to examine the relationship between fig wasp diversity and syconium diameter, and the effect of non-pollinating wasps on numbers of pollinators and seeds. Forty three species of fig wasp were identified, distributed across seven genera (Pegoscapus, Idarnes, Aepocerus, Physothorax, Anidarnes, Heterandrium, Eurytoma). Idarnes (carme group) was the wasps genus non-pollinator with greatest number of individuals with the greatest number of infested syconia ( 7409 wasps in 376 syconia). Analysing non-pollinating wasp diversity in relation to fig diameter, a significant difference was observed between the four fig species. Ficus citrifolia and F. americana subspecies guianensis form mathewsii had the smallest diameter but the greatest diversity of fig wasp. Ficus obtusifolia was the only species in which the non-pollinating wasps had a significant negative effect on the number of Pegoscapus sp. and on seed production.

KEYWORDS: Figs, diversity, Brazilian Amazon.

\section{Composição e estrutura da comunidade de vespas-de-figo na Amazônia}

\begin{abstract}
RESUMO
A compreensão sobre as complexas interaçôes ecológicas envolvendo vespas-de-figo e suas plantas hospedeiras na Amazônia depende do conhecimento prévio sobre a distribuição e diversidade dessas vespas. O objetivo deste estudo foi descrever a composição e estrutura da comunidade de vespas associadas a quatro espécies de Ficus no município de Manaus, Amazonas. Foram coletados e analisados 600 sicônios de quatro espécies: Ficus obtusifolia Kunth; Ficus citrifolia Mill; F. americana subspecies guianensis Desv. forma mathewsii; and F. americana subspecies guianensis Desv. forma parkeriana. Análises estatísticas foram usadas para analisar a relação entre a diversidade de vespas-de-figo e o diâmetro do sicônio, e o efeito das vespas nãopolnizadoras em relação ao número de polinizadoras e sementes. Foram encontradas 43 espécies de vespas-de-figo distribuídas em sete gêneros (Pegoscapus, Idarnes, Aepocerus, Physothorax, Anidarnes, Heterandrium, Eurytoma). Idarnes grupo carme foi o gênero de vespas não-polinizadora com maior numero de individuos com maior numero de sicônios infestado (7.409 vespas em 376 sicônios). Ao analisar a diversidade de vespas não-polinizadoras em relação ao diâmetro do figo observou-se diferença significativa entre as quatro espécies de figueiras. Ficus citrifolia e $F$ americana, subespécie guianensis, forma mathewsii apresentaram o diâmetro menor, porém uma maior diversidade de vespas-de-figo. Ficus obtusifolia foi a única espécie em que as vespas não-polinizadoras exerceram efeito negativo significativo tanto no número de Pegoscapus sp. quanto na produçáo de sementes.
\end{abstract}

PALAVRAS-CHAVE: Figueiras, Diversidade, Amazônia Brasileira. 


\section{INTRODUCTION}

Mutualistic interactions between plants and insects are of particular interest because the exchange of resources involved attracts a great variety of other organisms that benefit from the relationship (Bronstein 2001). A classic example is the relationship between the 750 species of the genus Ficus (Moraceae) and its pollinating wasps. The figs (syconia) are pollinated exclusively by specific wasps from the family Agaonidae (Chalcidoidea), which in turn reproduce by laying eggs in the fig's flowers (by preference the longerstyled flowers), where the larvae feed and develop (Kerdelhué and Rasplus 1996; Cook and Segar 2010). This mutualism is exploited by a number of other parasitic wasps - denominated non-pollinating wasps (Wiebes and Compton 1990) - and by innumerable species of ants, Homoptera, Coleoptera, Lepidoptera and Diptera (Yang et al. 2008; Bain et al. 2012).

Non-pollinating wasps are considered the main exploiters of the mutualism and they cover three ecological groups: gall-inducing wasps, parasites and cleptoparasites (Rasplus et al. 1998; Kjellberg et al. 2005). The gall inducers oviposit in flowers that have no existing galls and thus negatively affect both pollinating wasp production and fig seed production. The parasitic and cleptoparasitic wasps negatively affect only pollinator and other non-pollinator production (Kerdelhué e Rasplus 1996; West et al. 1996; Kerdelhué et al. 2000). However, the negative effects of non-pollinating wasps, whether in relation to seed production or pollinator production, can vary between fig trees and the regions in which they occur (Wei et al. 2005; Elias et al. 2007; Conchou et al. 2013). In the absence of any quantitative studies, it has not been possible until now to evaluate the effect of nonpollinating wasps on seed and pollinator production among Amazonian fig trees.

The exploitation of fig/wasp mutualism can also be observed by examining species abundance and richness among non-pollinating wasps, which vary enormously and depend on the biology of both wasp and fig tree (Bronstein 1992; Wang et al. 2012), as well as on external factors (Elias et al. 2007; Ma et al. 2009). There are cases of fig trees being exploited by six (Conchou et al. 2013), sixteen (Segar et al. 2013) or up to 30 species of non-pollinating wasp (Bouček 1993). In some cases the diversity of non-pollinating wasps may be closely related to the plant's reproductive systems (monoecious or dioecious) (Kerdelhué and Rasplus 1996). Monoecious species, for example, possess a greater diversity of wasps because they provide a larger number of niches (flowers) - of at least four types (heterostyly) - on which nonpollinating wasps may oviposit, while the pollinating wasps associated with the dioecious species are limited to just one type of flower (longer-styled flowers).
It can also be seen that, at least among monoecious species, the diversity of non-pollinating wasps varies in relation to fig diameter. Figs diameter normally varies between $4,0 \mathrm{~mm}$ and $60 \mathrm{~mm}$, and with 10 to 10,000 flowers respectively (Herre 1989; Berg and Wiebes 1992; Cook and Rasplus 2003). This potentially leads us to conclude that large-diameter figs will have the largest number of flowers and consequently a greater availability of locations for oviposition than figs of a smaller diameter. However, although this hypothesis has been proposed by Cook and Segar (2010), there are as yet no studies to corroborate the relationship. In the present study, we describe the composition and structure of the wasps community associated with four monoecious species of Ficus in the municipal area of Manaus, Amazonas, Brazil.

\section{MATERIALS AND METHODS}

The study was carried out in the urban area of the municipality of Manaus, Amazonas, Brazil (030.'S $60^{\circ} 01^{\prime} \mathrm{W}$ ), covering an area of $11,458.5 \mathrm{~km}^{2}$ (Saraiva et al. 2009). The city is located in central Amazonia, on the left bank of the River Negro and near the confluence of the River Negro with the River Solimóes. The climate is equatorial humid, with a mean annual temperature of $26.7^{\circ} \mathrm{C}$. Relative humidity is $80 \%$ and average annual rainfall is $2,286 \mathrm{~mm}$. The year has two distinct seasons: one humid, with significant rainfall from November to May; and one drier, between June and October (Alvares 2013).

Seven areas (districts) were selected for the study: Ponta Negra, Dom Pedro, São Geraldo, Cachoeirinha, Cidade Nova, Distrito Industrial and Flores. Four taxa were selected: Ficus obtusifolia Kunth; Ficus citrifolia Mill; F. americana subspecies guianensis form mathewsii; and F. americana subspecies guianensis form parkeriana. The latter two taxa according to the latest version of Berg (2007). All species and subspecies belonging to section Americana are pollinated exclusively by wasps of the genus Pegoscapus.

The choice of these taxa owes itself to their great abundance in urban fragments like squares and parks, and to their limited height ( \pm 7 metres) in these areas which facilitates the collection of syconia in all reproductive phases. It was not possible to select individuals within ecological reserves or undisturbed areas, because the height of individuals in these environments (above $25 \mathrm{~m}$ ) made it difficult to gather syconia from these trees.

Six hundred syconia were collected at random from four individuals (150 syconia from each fig tree) between July 2011 and October 2012. We selected figs that we judged to be in male phase (D stage sensu Galil and Eisikowitch 1968), but which did not yet have wasp exit holes. Such figs are relatively large and are often slightly soft when pressed between thumb and forefinger. 
The syconia were separated in plastic flasks covered with a voile type cloth, and kept for 48 hours to collect all the wasps. At the end of this time, the insects were killed by freezing, and subsequently a solution of $70 \%$ alcohol was added to the flasks, where the specimens were kept with their respective syconia before sorting (Costa and Graciolli 2010). The wasps that emerged from the syconia were sorted with the help of a stereoscopic magnifier (Nikon SMZ 645, Tokyo, Japan) and microscope (Primo Star; Carl Zeiss Microimaging, Jena, Germany), and identified at the level of morphospecies using Bouček's key for fig wasps of the New World (Bouček 1988; 1993; Farache et al. 2013). The wasp and Ficus specimens were deposited in the entomological collection and herbarium respectively at the Instituto Nacional de Pesquisa da Amazônia (INPA).

The largest diameter of 150 syconia (30 per fig tree) was measured using digital callipers. These syconia were dissected with the aid of a dissecting knife and stereoscopic magnifier in order to count the galls. Syconia of the species F. obtusifolia were divided in four separate equal parts, the galls counted for one of the parts, and the result multiplied by four. Syconia of the species F. citrifolia and F. americana subspecies guianensis form parkeriana were cut into two equal halves, the galls counted from one half and the result multiplied by two. For species $F$. americana subspecies guianensis form mathewsii, the total number of galls were counted individually (Kerdélhue and Rasplus 1996).

The quantitative distribution of fig wasp species for each host was calculated using the formula proposed by Bush et al. (1997), where the frequency of occurrence corresponds to

$$
\frac{N^{\circ} \text {. of infested syconia }}{N^{\circ} \text {. of syconia in sample }} \times 100
$$

while the mean intensity of infestation (Number of individuals of fig wasp species in a single host) corresponds to

$$
\frac{N^{\circ} \text {.of individuals in species } x}{N^{\circ} \text {. of syconia infested by species } x} \times 100
$$

To identify the fig tree species with the greatest wasp diversity, Shannon's index was employed, where $\mathrm{H}=-\sum \mathrm{P}_{\mathrm{i}}\left(\ln \mathrm{P}_{\mathrm{i}}\right)$, using the PAST 3.0 program. To analyse the relationship between fig wasp diversity and syconium diameter, Bioestat 5.0 was used. To define the type of statistic used - parametric or non-parametric - a normality test was performed a priori. To evaluate the relationship between syconium diameter and gall quantity, the Kruskal-Wallis Test was used, followed by the Dunn post-test. Spearman's correlation was used to examine the association between syconium diameter and gall quantity, as well as to estimate non-pollinating wasp species (male and female) richness and abundance in relation to syconium diameter. A 95\% significance level was used for all tests $(p<0.05)$.
To analyse the effect of the non-pollinating wasp species on the numbers of Pegoscapus and seeds, a simple linear regression was used with the number of individual wasps by genus for each host. The non-pollinating wasps were divided in two groups: 1) wasps with large bodies; and 2) wasps with smaller bodies, in relation to the body size of pollinating wasps. This division was done on the basis that the size of the galls of nonpollinating large-bodied wasps reduces the available space in the lumen of the syconia (Conchou et al. 2013).

\section{RESULTS}

The fig wasp community associated with the four fig trees comprised 43 morphospecies of fig wasp. Twenty nine morphospecies were encountered in F. citrifolia, 24 in $F$. americana subspecies guianensis form mathewsii, 18 in $F$. obtusifolia and seven in F. americana subspecies guianensis form parkeriana. The 43 morphospecies of fig wasp belong to three families and seven genera, with Aepocerus and Physothorax being those with the largest number of morphospecies (Table 1). The genus Idarnes was notable for having the greatest abundance and the largest number of infested syconia (Table 2).

The distribution index of the fig wasps in the syconia showed that Pegoscapus was the most prevalent genus in all the fig trees. In F americana subspecies guianensis form parkeriana the frequency of occurrence was $100 \%$ and mean intensity $120.7 \%$. F. americana subspecies guianensis form mathewsii had a frequency of occurrence of $98.6 \%$ and a mean intensity of $22.8 \%$; F citrifolia a frequency of $94.6 \%$ and mean intensity $75.8 \%$; and F obtusifolia a frequency of $99.3 \%$ and mean intensity of $186.8 \%$ Idarnes had the

Table 1. Summary of the number of morphospecies, total individuals, and infested syconia for each wasp genus associated with species Ficus in the

\begin{tabular}{|c|c|c|c|c|}
\hline $\begin{array}{l}\text { Fig wasp } \\
\text { Family/ } \\
\text { Subfamily }\end{array}$ & Wasp genus & $\begin{array}{c}\text { Number of } \\
\text { morphospecies }\end{array}$ & $\begin{array}{l}\text { Number of } \\
\text { individuals }\end{array}$ & $\begin{array}{l}\text { Number } \\
\text { of infested } \\
\text { syconia }\end{array}$ \\
\hline Agaonidae & Pegoscapus & 04 & 60,101 & 589 \\
\hline Sycophaginae & $\begin{array}{l}\text { Idarnes } \\
\text { (carme group) }^{\mathrm{a}}\end{array}$ & 06 & 7,409 & 376 \\
\hline Sycophaginae & $\begin{array}{l}\text { Idarnes } \\
\text { (flavicollis group) }^{\mathrm{a}}\end{array}$ & 01 & 14 & 6 \\
\hline \multirow[t]{2}{*}{ Sycophaginae } & $\begin{array}{l}\text { Idarnes } \\
\text { (incerta group) }\end{array}$ & 01 & 49 & 27 \\
\hline & Aepocerus ${ }^{\mathrm{b}^{*}}$ & 08 & 164 & 133 \\
\hline Torymidae & Physothorax ${ }^{\mathrm{b}}$ & 08 & 34 & 27 \\
\hline \multirow[t]{2}{*}{ Sycophaginae } & Anidarnes $^{\mathrm{b}}$ & 07 & 83 & 58 \\
\hline & Heterandrium ${ }^{\mathrm{a}^{*}}$ & 04 & 155 & 65 \\
\hline Eurytomidae & Eurytoma ${ }^{\mathrm{b}}$ & 06 & 45 & 34 \\
\hline
\end{tabular}
urban area of Manaus, Amazonas, Brazil.

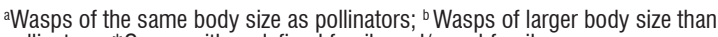
pollinators. *Genus with undefined family and/or subfamily 
Table 2. Quantitative distribution of fig wasp species in 600 syconia present in four species of Ficus in the urban area of Manaus, Amazonas, Brazil. The numbers of figs collected are in parentheses under the plant taxon column.

\begin{tabular}{|c|c|c|c|c|c|c|c|c|c|c|c|}
\hline 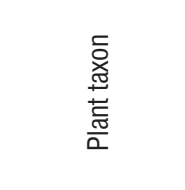 & 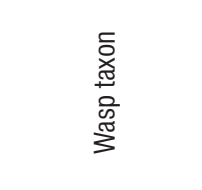 & 正 & 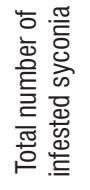 & 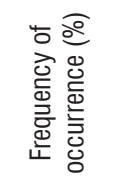 & 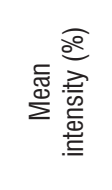 & 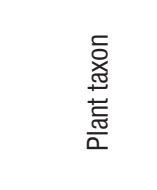 & 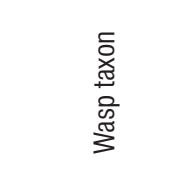 & 焉竞: & 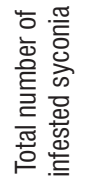 & 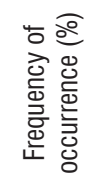 & 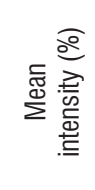 \\
\hline \multirow[t]{6}{*}{$\begin{array}{l}\text { form parkeriana } \\
(150)\end{array}$} & $\begin{array}{l}\text { Pegoscapus } \\
\text { sp.4 }\end{array}$ & 18,107 & 150 & 100.000 & 120.713 & & $\begin{array}{l}\text { Idarnes sp.5 } \\
\text { (carme group) }\end{array}$ & 185 & 14 & 9.333 & 13.214 \\
\hline & $\begin{array}{l}\text { Idarnes sp.2 } \\
\text { (carme group) }\end{array}$ & 47 & 14 & 9.333 & 3.357 & & $\begin{array}{l}\text { Idarnes sp.6 } \\
\text { (carme group) }\end{array}$ & 118 & 40 & 26.667 & 2.950 \\
\hline & $\begin{array}{l}\text { Idarnes sp.7 } \\
\text { (carme group) }\end{array}$ & 25 & 7 & 4.667 & 3.571 & & $\begin{array}{l}\text { Idarnes sp.7 } \\
\text { (carme group) }\end{array}$ & 166 & 19 & 12.667 & 8.737 \\
\hline & Aepocerus sp.8 & 6 & 3 & 2.000 & 2.000 & & $\begin{array}{l}\text { Idarnes sp.8 } \\
\text { (carme group) }\end{array}$ & 425 & 26 & 17.333 & 16.346 \\
\hline & $\begin{array}{l}\text { Heterandrium } \\
\text { sp.2 }\end{array}$ & 8 & 4 & 2.667 & 2.000 & & $\begin{array}{l}\text { Idarnes sp.4 } \\
\text { (incerta group) }\end{array}$ & 42 & 23 & 15.333 & 1.826 \\
\hline & Eurytoma sp.1 & 1 & 1 & 0.667 & 1.000 & & Aepocerus sp.1 & 22 & 14 & 9.333 & 1.571 \\
\hline \multirow[t]{21}{*}{$\begin{array}{l}\text { form mathewsii } \\
(150)\end{array}$} & $\begin{array}{l}\text { Pegoscapus } \\
\text { sp.3 }\end{array}$ & 3,380 & 148 & 98.667 & 22.838 & & Aepocerus sp.2 & 1 & 1 & 0.667 & 1.000 \\
\hline & $\begin{array}{l}\text { Idarnes sp. } 1 \\
\text { (carme group) }\end{array}$ & 201 & 43 & 28.667 & 4.674 & & Aepocerus sp.3 & 3 & 3 & 2.000 & 1.000 \\
\hline & Idarnes sp.2 & 36 & 11 & 7333 & 3273 & & Aepocerus sp.4 & 3 & 3 & 2.000 & 1.000 \\
\hline & (carme group) & & & 1.000 & 0.210 & & Aepocerus sp.7 & 49 & 31 & 20.667 & 1.581 \\
\hline & $\begin{array}{l}\text { Idarnes sp.5 } \\
\text { (carme group) }\end{array}$ & 23 & 7 & 4.667 & 3.286 & & $\begin{array}{l}\text { Physothorax } \\
\text { sp.1 }\end{array}$ & 2 & 2 & 1.333 & 1.000 \\
\hline & $\begin{array}{l}\text { Idarnes sp.3 } \\
\text { (flavicolis group) }\end{array}$ & 9 & 2 & 1.333 & 4.500 & & $\begin{array}{l}\text { Physothorax } \\
\text { sp.5 }\end{array}$ & 2 & 2 & 1.333 & 1.000 \\
\hline & $\begin{array}{l}\text { Idarnes sp.4 } \\
\text { (incerta group) }\end{array}$ & 3 & 1 & 0.667 & 3.000 & & $\begin{array}{l}\text { Physothorax } \\
\text { sp.6 }\end{array}$ & 2 & 1 & 0.667 & 2.000 \\
\hline & Aepocerus sp.1 & 3 & 3 & 2.000 & 1.000 & & Physothorax & 2 & 2 & 1.333 & 1.000 \\
\hline & Aepocerus sp.3 & 14 & 9 & 6.000 & 1.556 & & & & & & \\
\hline & Aepocerus sp.5 & 3 & 2 & 1.333 & 1.500 & & $\begin{array}{l}\text { Physothorax } \\
\text { sp.8 }\end{array}$ & 7 & 6 & 4.000 & 1.167 \\
\hline & Aepocerus sp.6 & 1 & 1 & 0.667 & 1.000 & & Anidarnes sp.4 & 1 & 1 & 0.667 & 1.000 \\
\hline & Aepocerus sp.7 & 10 & 8 & 5.333 & 1.250 & & Anidarnes sp.7 & 8 & 6 & 4.000 & 1.333 \\
\hline & Anidarnes sp.2 & 6 & 2 & 1.333 & 3.000 & & Anidarnes sp.8 & 1 & 1 & 0.667 & 1.000 \\
\hline & Anidarnes sp.4 & 15 & 12 & 8.000 & 1.250 & & $\begin{array}{l}\text { Heterandrium } \\
\text { sp.1 }\end{array}$ & 45 & 20 & 13.333 & 2.250 \\
\hline & Anidarnes sp.5 & 5 & 5 & 3.333 & 1.000 & & Heterandrium & 1 & 1 & 0.667 & 1.000 \\
\hline & Anidarnes sp.6 & 4 & 3 & 2.000 & 1.333 & & & & & & \\
\hline & $\begin{array}{l}\text { Heterandrium } \\
\text { sp.1 }\end{array}$ & 93 & 33 & 22.000 & 2.818 & & $\begin{array}{l}\text { Heterandrium } \\
\text { sp.3 }\end{array}$ & 6 & 6 & 4.000 & 1.000 \\
\hline & Eurytoma sp.2 & 5 & 4 & 2.667 & 1.250 & & $\begin{array}{l}\text { Heterandrium } \\
\text { sp.4 }\end{array}$ & 2 & 1 & 0.667 & 2.000 \\
\hline & Eurytoma sp.3 & 1 & 1 & 0.667 & 1.000 & & Eurytoma sp.2 & 8 & 7 & 4.667 & 1.143 \\
\hline & Eurytoma sp.4 & 5 & 2 & 1.333 & 2.500 & & Eurytoma sp.3 & 16 & 12 & 8.000 & 1.333 \\
\hline & Eurytoma sp.5 & 2 & 2 & 1.333 & 1.000 & & Eurytoma sp.6 & 7 & 5 & 3.333 & 1.400 \\
\hline \multirow[t]{3}{*}{$\begin{array}{l}\text { F. citrifolia } \\
(150)\end{array}$} & $\begin{array}{l}\text { Pegoscapus } \\
\text { sp.2 }\end{array}$ & 10,767 & 142 & 94.667 & 75.824 & $\begin{array}{l}\text { F. obtusifolia } \\
(150)\end{array}$ & $\begin{array}{l}\text { Pegoscapus } \\
\text { sp.1 }\end{array}$ & 27,847 & 149 & 99.333 & 186.893 \\
\hline & $\begin{array}{l}\text { Idarnes sp.1 } \\
\text { (carme group) }\end{array}$ & 1,145 & 48 & 32.000 & 23.854 & & $\begin{array}{l}\text { Idarnes sp.1 } \\
\text { (carme group) }\end{array}$ & 2,294 & 46 & 30.667 & 49.870 \\
\hline & $\begin{array}{l}\text { Idarnes sp.2 } \\
\text { (carme group) }\end{array}$ & 259 & 20 & 13.333 & 12.950 & & $\begin{array}{l}\text { Idarnes sp.2 } \\
\text { (carme group) }\end{array}$ & 2,466 & 77 & 51.333 & 32.026 \\
\hline
\end{tabular}


Table 2. Continuation

\begin{tabular}{|c|c|c|c|c|c|}
\hline 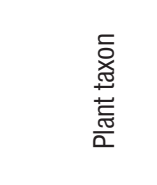 & 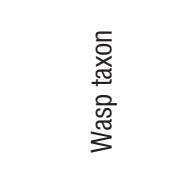 & 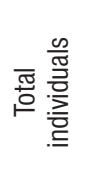 & 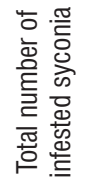 & 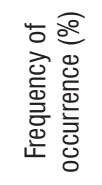 & 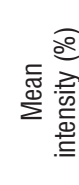 \\
\hline \multirow[t]{14}{*}{$\begin{array}{l}\text { F. obtusifolia } \\
(150)\end{array}$} & $\begin{array}{l}\text { Idarnes sp.5 } \\
\text { (carme group) }\end{array}$ & 19 & 4 & 2.667 & 4.750 \\
\hline & $\begin{array}{l}\text { Idarnes sp.3 } \\
\text { (flavicolis group) }\end{array}$ & 5 & 4 & 2.667 & 1.250 \\
\hline & $\begin{array}{l}\text { Idarnes sp.4 } \\
\text { (incerta group) }\end{array}$ & 4 & 3 & 2.000 & 1.333 \\
\hline & Aepocerus sp.5 & 21 & 13 & 8.667 & 1.615 \\
\hline & Aepocerus sp.6 & 5 & 3 & 2.000 & 1.667 \\
\hline & Aepocerus sp.7 & 2 & 2 & 1.333 & 1.000 \\
\hline & $\begin{array}{l}\text { Physothorax } \\
\text { sp.1 }\end{array}$ & 6 & 4 & 2.667 & 1.500 \\
\hline & $\begin{array}{l}\text { Physothorax } \\
\text { sp.2 }\end{array}$ & 1 & 1 & 0.667 & 1.000 \\
\hline & $\begin{array}{l}\text { Physothorax } \\
\text { sp.3 }\end{array}$ & 1 & 1 & 0.667 & 1.000 \\
\hline & $\begin{array}{l}\text { Physothorax } \\
\text { sp.4 }\end{array}$ & 1 & 1 & 0.667 & 1.000 \\
\hline & Anidarnes sp.1 & 16 & 9 & 6.000 & 1.778 \\
\hline & Anidarnes sp.2 & 22 & 15 & 10.000 & 1.467 \\
\hline & Anidarnes sp.3 & 2 & 2 & 1.333 & 1.000 \\
\hline & Eurytoma sp.1 & 1 & 1 & 0.667 & 1.000 \\
\hline
\end{tabular}

greatest frequency and mean intensity in all the fig trees. In F. obtusifolia the morphospecies Idarnes sp.2 (carme group) had the greatest frequency (51.33\%) and Idarnes sp. 1 (carme group) the greatest mean intensity ( $49.8 \%$, Table 2$)$.

Regarding the diversity of non-pollinating wasps in relation to fig diameter (in millimeters), a significant difference was observed among the four fig species. Ficus americana subspecies guianensis form mathewsii and F. citrifolia were the species with the smallest figs, mean $( \pm S D)$ of $4.62 \pm 0.52$ and $9.61 \pm 1.91$ respectively, but had the largest Shannon index at $\mathrm{H}=1.829$ and $\mathrm{H}=1.835$ respectively (Table 3 ). In F. obtusifolia (figs with a diameter almost 4 times larger than that of $F$. americana subspecies guianensis form mathewsii) the Shannon index was $\mathrm{H}=0.828$. It was also found that species richness of wasps is not correlated with fig diameter in F. Americana subspecies guianensis form mathewsii and F. citrifolia, although there is a correlation between wasp species abundance and fig diameter in both fig trees. For $F$ americana subspecies guianensis form parkeriana, species richness is correlated with fig diameter, mean $( \pm S D)$ of $12.0 \pm 1.25$, while species abundance is not. In species F obtusifolia both richness and abundance are correlated with fig diameter, mean $( \pm S D)$ of $16.57 \pm 2.62$ (Table 3 ).

In relation to the effect of non-pollinating wasps on the number of pollinating wasps and seeds, in $F$ citrifolia wasps of the genus Idarnes represented $92.37 \%$ of all individuals. Among large-bodied non-pollinating species, Aepocerus was the most abundant with $54.48 \%$ of the individuals. In $F$ americana subspecies guianensis form mathewsii, $76.92 \%$ of nonpollinating wasps were represented by Idarnes and Heterandrium (wasps with the same body size as the pollinating wasps). In F. americana subspecies guianensis form parkeriana, $82.6 \%$ of non-pollinating wasps were represented by Idarnes. For these three species of Ficus, the total number of non-pollinating wasps did not correlate negatively with either the number of Pegoscapus or the number of seeds (Figures 1-3 A, B).
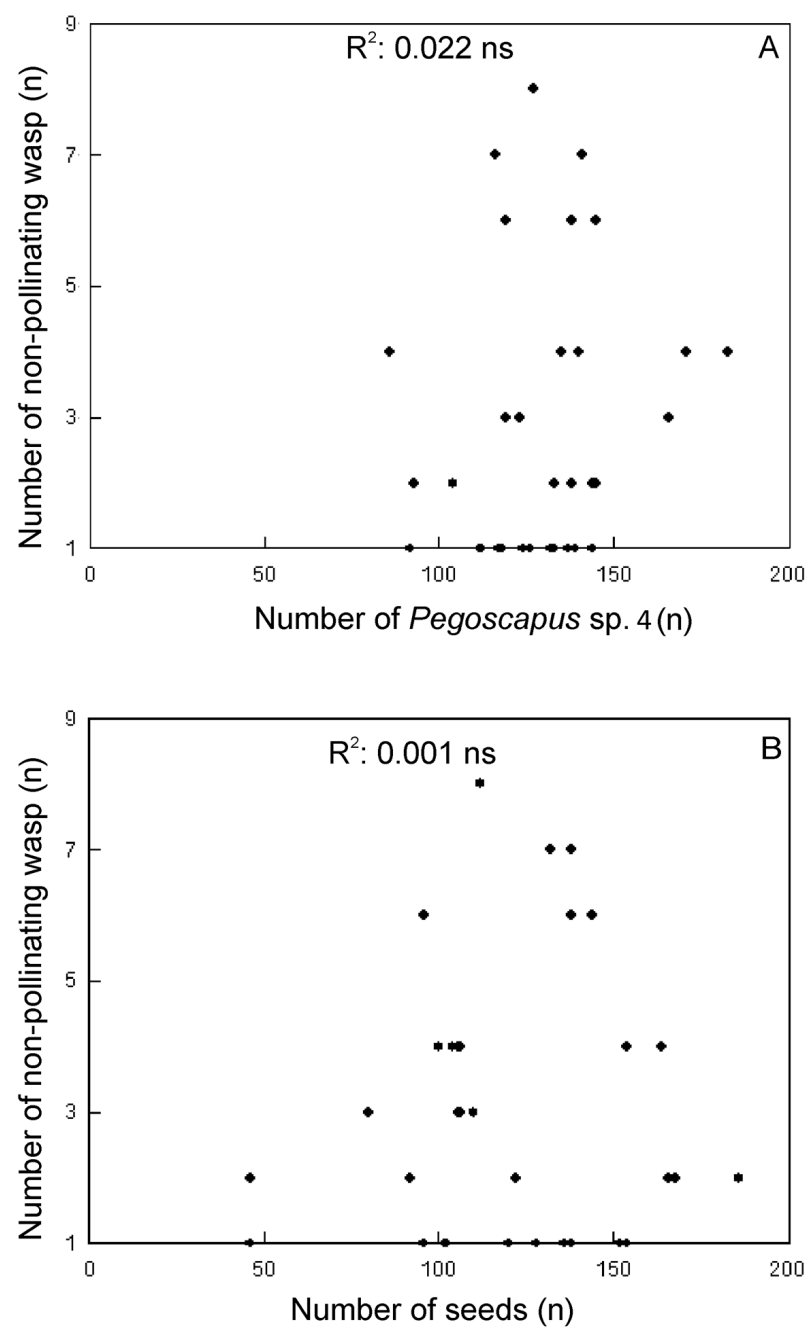

Figure 1. Number of non-pollinating fig wasps as a function of the number of Pegoscapus sp. 4 (A), and the number of seeds (B) in F. americana subspecies guianensis form parkeriana. 
Table 3. Syconium diameter (mm), number of galls, richness and abundance of non-pollinating fig wasps, and Shannon diversity index for different species of Ficus in the urban areas of Manaus, Amazonas, Brazil. Acronyms: SD standard deviation; $\boldsymbol{P}$ * represent significant differences; rs are Spearman's correlation; df degrees of freedom.

\begin{tabular}{|c|c|c|c|c|c|c|c|c|c|c|}
\hline \multirow{2}{*}{ Plant taxon } & \multirow{2}{*}{$\begin{array}{c}\text { Diameter } \\
\text { mean } \pm \text { SD }\end{array}$} & \multirow{2}{*}{$P^{\star}$} & \multirow{2}{*}{$\begin{array}{c}\text { Galls } \\
\text { mean } \pm \text { SD }\end{array}$} & \multirow{2}{*}{$\begin{array}{l}\text { Shannon } \\
\text { index (H) }\end{array}$} & \multicolumn{3}{|c|}{ Richness } & \multicolumn{3}{|c|}{ Abundance } \\
\hline & & & & & $P^{*}$ & $\mathrm{df}$ & $\mathrm{rs}^{*}$ & $P^{*}$ & df & rs \\
\hline parkeriana $^{1}$ & $12.0 \pm 1.25$ & $B$ & $128.3 \pm 23.89$ & 1.146 & $=0.0079$ & 148 & $=0.2161$ & $=0.6505$ & 148 & $=0.0379$ \\
\hline mathewsii & $4.62 \pm 0.52$ & A & $29.3 \pm 14.10$ & 1.829 & $=0.6252$ & 148 & $=0.0735$ & $=0.2125$ & 148 & $=0.1018$ \\
\hline F. citrifolia & $9.61 \pm 1.91$ & C & $105.0 \pm 55.03$ & 1.835 & $=0.9587$ & 148 & $=0.0042$ & $=0.0123$ & 148 & $=0.2028$ \\
\hline F. obtusifolia & $16.57 \pm 2.62$ & D & $252.9 \pm 87.48$ & 0.828 & $=0.0051$ & 148 & $=0.2289$ & $<0.0001$ & 148 & $=0.4815$ \\
\hline
\end{tabular}

${ }^{\star}$ Dunn test, $95 \%$ significance level. Letters in column $\boldsymbol{P}^{\star}$ represent significant differences in mean values between fig diameters of the fig tree species. Forms belonging to ${ }^{1} F$. americana subspecies guianensis form Parkeriana, ${ }^{2}$ Ficus americana subspecies guianensis form mathewsii according to Berg (2007).
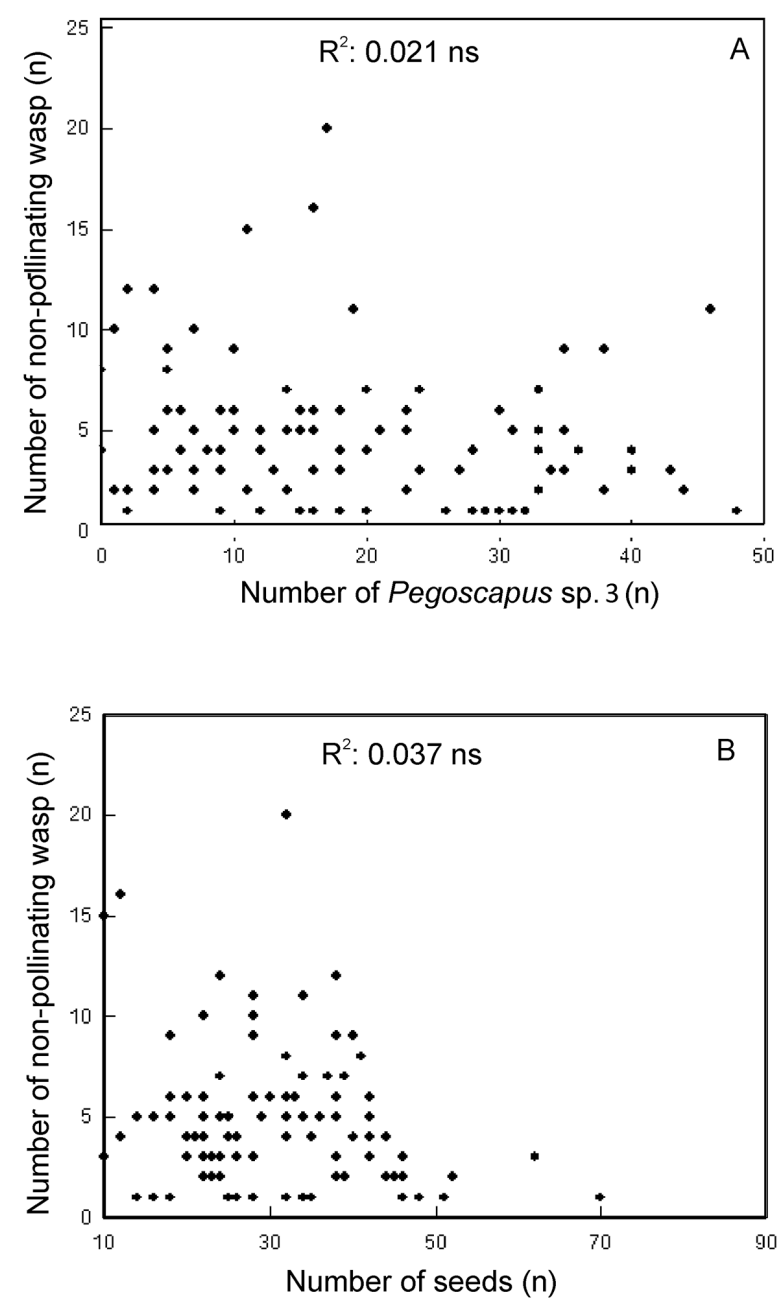

Figure 2. Number of non-pollinating fig wasps as a function of the number of Pegoscapus sp. 3 (A), and the number of seeds (B) in F. americana subspecies guianensis form mathewsii.
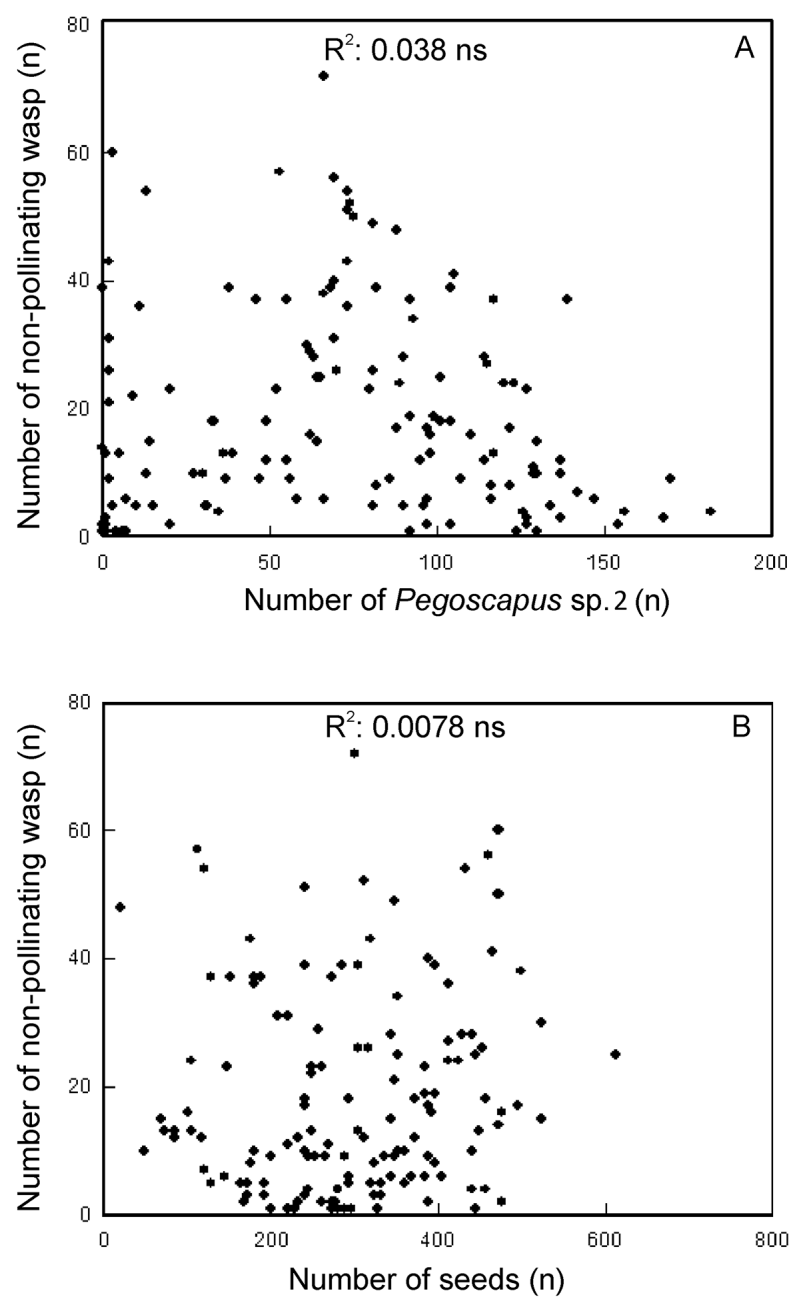

Figure 3. Number of non-pollinating fig wasps as a function of the number of Pegoscapus sp. 2 (A), and the number of seeds (B) in F. citrifolia. 
In F. obtusifolia the non-pollinating wasps were present in 124 of the 150 syconia, represented principally by wasps of the genus Idarnes (98.92\%). Due to the low number of non-pollinating large-bodied wasps, simple regression analysis was performed only for wasps of the genus Idarnes. The results showed that the total number of non-pollinating wasp correlated negatively and significantly with both the number of Pegoscapus sp. $1\left(r^{2}: 0.44, p<0.0001\right)$, (Figure 4A), and the number of seeds $\left(r^{2}=0.44, p<0.0001\right)$ (Figure $\left.4 \mathrm{~B}\right)$.

\section{DISCUSSION}

The present study is the first to provide quantitative and qualitative data on fig wasp fauna in the Amazon region. In comparison with studies in the southeast and centre-west of Brazil, it was found that the wasp fauna associated with
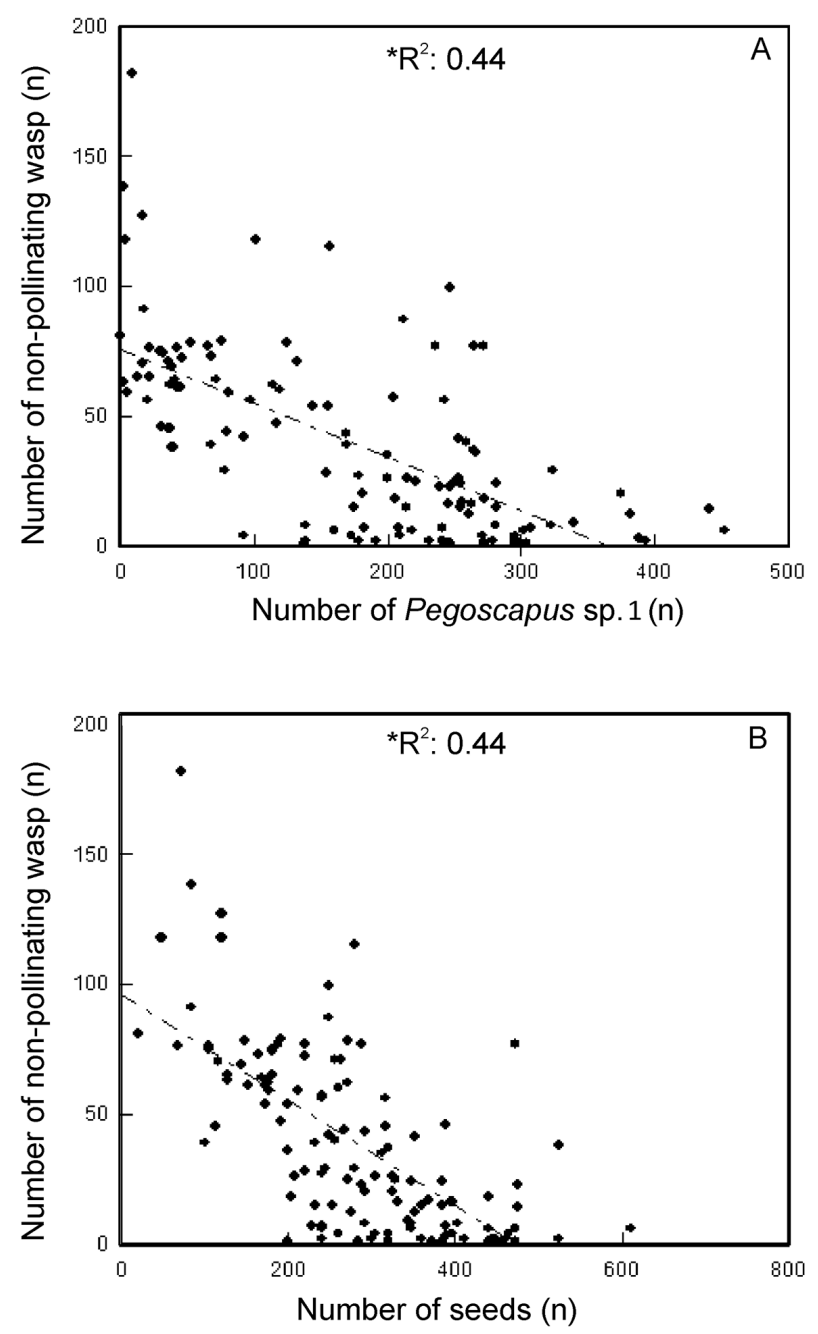

Figure 4. Number of non-pollinating fig wasps as a function of the number of Pegoscapus sp. 1 (A), and the number of seeds (B) in F. obtusifolia.
Amazonian fig trees is more diverse. The wasp community in $F$ c citrifolia in this study comprised 29 species, while in Mato Gross do Sul (Costa and Graciolli 2010), São Paulo and Londrina (Pereira et al. 2000), 12 and 15 species were registered respectively. The same was confirmed for $F$ americana subspecies guianensis form mathewsii which here contained 22 species in comparison with those in the study by Conchou et al. (2013) in French Guiana, with just six species. This is the first study, in which such a large number of non-pollinating wasp species has been registered, and given the diversity of fig trees in the neotropics (140 species) it is likely that there are many more species of fig wasp in the Amazon yet to be described.

The results showed that the morphospecies Pegoscapus and Idarnes (carme group) were the most frequently occurring and abundant. Among the non-pollinating wasps, Idarnes is commonly regarded as the most abundant and diverse in Central and South America (West and Herre 1994; Elias et al. 2007; Costa and Graciolli 2010). In the case of Idarnes (carme group) (cleptoparasites), success in exploiting the mutualism is evidenced partly by the fact that the species in this group oviposits during phase $\mathrm{C}$ - the plant's interfloral phase (Murussich and Machado 2007; Elias et al. 2008). This phase, being the longest (18 to 20 days depending on the species of Ficus), gives an advantage to wasps from the carme group in ovipositing in a larger number of galls. In addition, the larvae of the males of this group have been observed feeding on the seeds, which broadens the spectrum of alimentary resources and the chances of increasing the progeny (Pereira et al. 2007).

For the morphospecies of Idarnes of the group incerta and flavicollis (gall-inducers and phytophagous competitors), one of the factors that may influence the low frequency and/or abundance of the species is the short time available (seven to eight days) for oviposition. As they oviposit a little before or at the same time as the pollinators (Elias et al. 2008), they compete for location and thus reduce the chances of ovipositing due to the limited availability of resources (flowers) for larvae development. The same may be happening with morphospecies of the genus Aepocerus and Heterandrium (gall inducers), which oviposit approximately seven to twelve days prior to pollination (Rasplus and Soldati 2006). The genera Physothorax (Hanson 2006) and Eurytoma, (Burks 1971) are the last to colonise the syconia and are parasites of the larvae of the phytophagous species (West et al. 1996; Murussich and Machado 2007; Cruaud et al. 2011). Therefore, even though no data have been presented with respect to the feeding habits of the wasps, it is possible to infer that the period of ovipositing (during the reproductive phase of the fig) and the presence of the wasp host in the syconia could be influencing the frequency and/or abundance of the parasitoid wasp species.

In relation to fig wasp species diversity, F. citifolia and F. americana subspecies guianensis form mathewsii (syconia 
of smaller diameter) contained the greatest diversity, while $F$. obtusifolia (syconia of larger diameter) had a low Shannon index. Consequently, our data failed to support the hypothesis postulated by Cook and Segar (2010) which predicted that larger diameter syconia would have a greater range of niches and the greatest wasp species richness. However, the timing difference in fig production (the interval between harvests) among species observed during our fieldwork, allows us to suggest that phenological aspects may be, in part, influencing normal fig wasp diversity. Individuals of $F$. obtusifolia and $F$ americana, subspecies guianensis form parkeriana were observed to fruit just twice a year. For $F$. citrifolia and $F$. americana subspecies guianensis form mathewsii fruiting occurred four times a year. Twice yearly fig production for $F$. obtusifolia was also observed in the studies of Ballestrini et al. (2011) in Venezuela and Panama. In the same way, Cerezini et al. (2007) observed that fig production in F. citrifolia may occur continuously throughout the year.

Considering that the greater the frequency of availability of the flowers, the greater the probability of an available niche suitable for reproduction, it appears that $F$ americana subspecies guianensis form mathewsii and F. citrifolia, are being selected by non-pollinating wasps as preferred species for the development of their larvae because both species flower up to four times per annum (personal observation). The limited period of time available for wasps to identify figs in which to lay eggs, the impact of adverse weather conditions and the effects of predation on the chances of successful reproduction (Kjellberg et al. 1988), are other factors which might tend to encourage such selection. In addition, even though there is a certain degree of specificity between non-pollinating wasps and host plants (Cook and Rasplus 2003), the wasps will select the fig species that are available in the period when they are ready for laying. For this to occur, it is necessary that the figs have at least some similar morphological characteristics. Phenoptic diversity with respect to syconium size indirectly causes the restriction of a considerable number of non-pollinating wasps, since large figs have a thicker receptacle wall which does not allow some species to reach the flower ovules during oviposition (Dunn et al. 2008).

With respect to the negative effect of the non-pollinating wasps on the numbers of Pegoscapus sp. 1 and seeds, $F$. obtusifolia was the only species that indicated a significant negative effect, caused specifically by Idarnes (carme group, wasps with the same body size as the pollinating wasps). According to Conchou et al. (2013), at least in small figs the development of large galls inside recently pollinated figs may reduce the amount of space available for the development of pollinator galls and seeds. Based on this premise, it is suggested that the presence of a smaller number of largebody non-pollinating wasps in $F$ obtusifolia, may explain the significant negative effect of the species of Idarnes (carme group) on this species and not on $F$ americana subspecies guianensis form mathewsii and F. citrifolia. This is because the absence of large galls makes viable not only the production of a larger number of small galls, but also of seeds, which are the two resources used in gall development in Idarnes (carme group). However, caution is necessary in accepting this relationship since the effects on mutualism vary according to the ecology and biology of each one of the non-pollinating wasps involved (Bronstein 1992).

\section{CONCLUSION}

Our study provides significant evidence that wasp fauna associated with the figs of Amazonia is more diverse than in other regions of Brazil. It has also shown that non-pollinating fig wasp diversity varies in relation to fig diameter, but that figs of a large diameter are not necessarily those which host the greatest wasp diversity.

The interval between harvests - shorter in fig species with smaller figs - may influence the structure of the non-pollinating wasp community. Although non-pollinating wasps affect seed and pollinator production in one of the four fig species, our study suggests that the probably of the mutualism being negatively affected by the parasitic wasps can be considered low in the urban Amazonian environment. This work will provide a foundation for other studies on Amazonian fig wasp species.

\section{ACKNOWLEDGMENTS}

To the Fundação de Amparo à Pesquisa do Estado do Amazonas (FAPEAM) for scholarship to RRSC. To Nilton Lins University for the physical space provided. To Dr. F.H.A. Farache for help in fig wasps identification.

\section{REFERENCES}

Alvares, C.A.; Stape, J.L; Sentelhas, P.C; Gonçalves, J.L.M; Sparovek, G. 2013. Koppen's climate classification map for Brazil. Meteorologische Zeitschrift, 22: 711-728.

Ballestrini, C.; Wilmer, T.; Herrera, A. 2011. Environmental drivers of leaf phenology in trees of the tropical species Ficus obtusifolia. Brazilian Journal of Plant Physiology, 23: 113-122.

Berg, C.C.; Wiebes, J.T. 1992. African fig trees and fig wasp. NorthHolland, Amsterdam, New York, 298p.

Berg, C.C. 2007. Proposals for treating four species complexes in Ficus subgenus Urostigma section Americanae (Moraceae). Blumea, 52: 295-312.

Berg CC. Proposals for treating four species complexes in Ficus subgenus Urostigma section Americanae (Moraceae). BLUMEA 2007; 52: 295-312. 
Berg CC. Proposals for treating four species complexes in Ficus subgenus Urostigma section Americanae (Moraceae). BLUMEA 2007; 52: 295-312.

Bain, A.; Chantarasuwan, B.; Hossaert-McKey, M.; Schatz, B.; Kjellberg, F.; Chou, L.S. 2012. A new case of ants nesting within branches of a fig tree: the case of Ficus subpisocarpa in Taiwan. Sociobiology, 59: 415-434.

Bouček, Z. 1988. Australian Chalcidoidea (Hymenoptera): A biosystematic revision of genera of fourteen families, with a reclassification of species. CAB International, Wallingford, 832p.

Bouček, Z. 1993. The genera of chalcidoid wasp from Ficus fruit in the New World. Journal Nature History, 27: 173-217.

Bronstein, J.L. 1992. Seed predator as mutualists: Ecology and evolution of the fig pollinator interaction. In: Bernays, E. (Ed.). Insect-Plant Interactions, CRC Press, Boca Raton, p.1-43.

Bronstein, J.L. 2001. The exploitation of mutualisms. Ecology Letters, 4: $277-287$.

Burks, B.D.A. 1971. A synopsis of the genera of the family Eurytomidae (Hymenoptera: Chalcidoidea). Transactions of the American Entomological Society, 97: 1-89.

Bush, A.O.; Lafferty, K.D.; Lotz, J.M.; Shostak, A.W. 1997. Parasitology meets ecology on its own terms: Margolis et al. revisited. Journal of Parasitology, 83: 575-83.

Cerezini, M.T.; Gobbo, S.E.; Pereira R.A.S. 2007. Fenologia e disponibilidade de polinizadores de Ficus citrifolia no município de Ribeirão Preto, estado de São Paulo. Anais do VIII Congresso de Ecologia do Brasil. Caxambu-MG.

Conchou, L.; Ciminera, M.; Hossaert-McKey, M.; Kjellberg, F. 2013. The non-pollinating fig wasps associated with Ficus guianensis: Community structure and impact of the large species on the fig/ pollinator mutualism. Acta Oecologica, 57: 1-10.

Cook, J.M.; Rasplus, J.Y. 2003. Mutualists with attitude: coevolving fig wasps and figs. Trends in Ecology and Evolution, 18: 241-248.

Cook, J.M.; Segar, S.T. 2010. Speciation in fig wasps. Ecology Entomology, 35: 54-66.

Costa, P.C.; Graciolli, G. 2010. Insects associated with syconia of Ficus citrifolia (Moraceae) in central Brazil. Revista Brasileira de Entomologia, 54: 707-709

Cruaud, A.; Zahab, R.J.; Gerson, G.; Kjellberg, F.; Kobmoo, N.; Simon, V.N. et al. 2011. Phylogeny and evolution of life-history strategies in the Sycophaginae non-pollinating fig wasps (Hymenoptera, Chalcidoidea). BMC Evolutionary Biology, 11: 178.

Dunn, D.W.; Segar, S.T.; Ridley, J.; Chan, R.; Crozier, R.H.; Yu, D.W.; Cook, J.M. 2008. A role for parasites in stabilising the fig-pollinator mutualism. PloS Biology, 6: 59.

Elias, L.G.; Ó, V.T.; Farache, F.H.A.; Pereira, R.A.S. 2007. Efeito de vespas não-polinizadoras sobre o mutualismo Ficus - vespas de figos. Iheringia, Série Zoologia 97: 253-256.

Elias, L.G.; Menezes, J.R.A.O.; Pereira, R.A.S. 2008. Colonization sequence of non-pollinating fig wasps associated with Ficus citrifolia in Brazil. Symbiosis, 45: 107-11.

Farache, H.A.F.; Astrid, C.; Gwena, E.G.; Pereira, A.S.P.; Jean-Yves, S.R. 2013. Taxonomic revision and molecular phylogeny of the fig wasp genus Anidarnes Bouček, 1993 (Hymenoptera: Sycophaginae). Systematic Entomology, 38: 14-34.

Galil, J.; Eisikowitch, D. 1968. On the pollination ecology of Ficus sycomoru in East Africa. Ecology, 49: 259-69.

Hanson, P.E. 2006. Familia Torymidae. In Fernández, F.; Sharkey, M.J. Introducción a los Hymenoptera de la Región Neotropical. (Ed.). Sociedad Colombiana de Entomología \& Universidad Nacional de Colombia, Bogotá, p.699-702.

Herre, E.A. 1989. Coevolution of reproductive characteristics in 12 species of New World figs and their pollinator wasps. Experientia, 45: 637-647.

Kerdelhue, C.; Rasplus, J.Y. 1996. Non-pollinating Afrotropical fig wasps affect the fig-pollinator mutualism in Ficus within the subgenus Sycomorus. Oikos, 75: 3-14.

Kerdelhué, C.; Rossi, J.P.; Rasplus, J.Y. 2000. Comparative community ecology studies on Old World figs and fig wasps. Ecology, 81: 2832-2849.

Kjellberg, F.; Doumesche, B.; Bronstein, J.L. 1988. Longevity of a fig wasp (Blastophagapsenes). Proceeding of the Koninklijke Nederlandse Akademie van Wetenschappen (C), 91: 117-122.

Kjellberg, F.; Jousselin, E.; Hossaert-McKey, M.; Rasplus, J.Y. 2005. Biology, ecology and evolution of fig-pollinating wasps (Chalcidoidea, Agaonidae). In: Raman, A., Schaefer, C.W.; Withers, T.M. (Eds.) Biology, ecology and evolution of gall-inducing arthropods. v.2. New Hampshire, Science, p.539-572.

Ma, W.J.; Yang, D.R.; Peng, Y.Q. 2009. Disturbance effects on community structure of Ficus tinctoria fig wasps in Xishuangbanna, China: implications for the fig/fig wasp mutualism. Insect Science, 16: 417-424.

Marussich, W.A.; Machado, C.A. 2007. Host-specificity and coevolution among pollinating and non-pollinating. New World fig wasps. Molecular Ecology, 16: 925-946.

Pereira, R.A.S.; Semir, J.; Menezes Jr, A.O.B. 2000. Pollination and other biotic interactions in figs of Ficus eximia Schott (Moraceae). Brazilian Journal of Botany, 23: 217-24.

Pereira, R.A.S.; Rodrigues, E.; Menezes, A.O. Jr. 2007. Phenological patterns of Ficus citrifolia (Moraceae) in a seasonal humidsubtropical region in South Brazil. Plant Ecology, 188: 265-275.

Rasplus, J.Y.; Kerdelhué, C.; Le Clainche, I.; Mondor, G. 1998. Molecular phylogeny of fig wasps (Hymenoptera). Agaonidae are not monophyletic. Compte Rendu de l'Académie des Sciences de Paris, 321: 517-527.

Rasplus, J.Y.; Soldati, L. 2006. Familia Agaonidae. p. 683- 698. In: Fernández, F. \& Sharkey, M. J. (eds.). Introducción a los Hymenoptera de la Región Neotropical. Bogotá, Sociedad Colombiana de Entomología \& Universidad Nacional de Colombia 896 p.

Saraiva, M. das G.; Amorim, R.D.S.; Moura, M.A.S.; MartinezEspinosa, F.E.; Vale Barbosa, M. das G. 2009. Expansão urbana e distribuição espacial da malária no município de Manaus, Estado do Amazonas. Revista da Sociedade Brasileira de Medicina Tropical, 42: 515-22.

Segar, T.S.; Derek W.D.; Clive T.D.; James M. C. 2013. How to be a fig wasp down under: The diversity and structure of an Australian fig wasp community. Acta Oecologica, 57: 17-27. 
Wang, H.; Ridley, J.; Dunn, D.W.; Wang, R.; Cook, J.M.; Yu, D.W. 2012. Biased oviposition and biased survival together help resolve a fig-wasp conflict. Oikos, 122: 533-540.

Wei, Z.D.; Peng, Y.Q.; Xu, L.; Yang, D.R. 2005. Impact of Oecophylla smaragdina on the percentage number of offspring of pollinator and nonpollinating wasps on Ficus racemosa. Zoological Research, 26: 386-390.

West, S.A.; Herre, E.A. 1994. The ecology of the New World figparasitising wasps Idarnes and implications for the evolution of the fig-pollinator mutualism. Proceeding of Royal Society of London B, 258: 67-72.

West, S.A.; Herre, E.A.; Windsor, D.M.; Green, P.R.S. 1996. The ecology and evolution of the New World non-pollinating fig wasp communities. Journal of Biogeography, 23: 447-458.
Wiebes, J.T.; Compton, S.G. 1990. Agaonidae (Hymenoptera Chalcidoidea) and Ficus (Moraceae): fig wasps and their figs, VI (Africa concluded). Proceedings of the Koninklijke Nederlandse Akademie van Wetenschappen, 93: 203-222.

Yang, D.R.; Peng, Y.P.; Yang, P.; Guan, J.M. 2008. The community structure of insects associated with figs at Xishuangbanna, China. Symbiosis, 45: 153-157.

Recebido em 20/01/2015

Aceito em 14/05/2015 